Eixo Temático: Processos de Ensino-Aprendizagem

\title{
ET-06-006 \\ PROTAGONISMO DE PIBIDIANOS EM ATIVIDADES EXTRACLASSE NO ENSINO FUNDAMENTAL EM UM COLÉGIO DA EDUCAÇÃO BÁSICA DE ALAGOINHAS- BA
}

Luciana Maria de Oliveira Souza ${ }^{1 \cdot 3}$, Jamile Braz Santos ${ }^{13}$, Bruna de Sousa Silva ${ }^{1},{ }^{3}$ Maria Tereza Nonato Costa $^{1,3}$, Eltamara Souza da Conceição ${ }^{2,3}$

${ }^{1}$ Bolsista PIBID-UNEB/CAPES.

${ }^{2}$ Coordenadora de Área PIBID-UNEB/CAPES.

${ }^{3}$ Universidade do Estado da Bahia. DCET II - Campus de Alagoinhas. Rod. AlagoinhasSalvador, BR 100, KM 03, Alagoinha-BA. CEP 48040-210. luciana.souza1@hotmail.com; jamilebrazsantos@gmail.com; bruninhaa1994@hotmail.com; teca_nonato@hotmail.com; elta_mara@yahoo.com.br.

\section{http://dx.doi.org/10.21472/congrebio2016.et-06-006}

\section{RESUMO}

Atualmente, os professores da rede básica ainda têm enfrentado um grande desafio ao realizar o ensino de Ciências, diante das condições das escolas, características dos estudantes e instrumentos pedagógicos disponíveis. Desse modo, cabe ao professor, como mediador na construção do conhecimento, propiciar um espaço em sala de aula, que possa atrair a atenção dos alunos, utilizando-se de práticas pedagógicas motivadoras para melhoria no processo de ensino aprendizagem e estreitamento das relações interpessoais. Os pibidianos do Departamento de Ciências Exatas da UNEB, de Alagoinhas, têm vivenciado isso cotidianamente na escola, protagonizando atividades diversas que têm corroborado para a melhoria da aprendizagem no ensino de Ciências. Assim, desenvolveu-se um trabalho experimental com estudantes do $6^{\circ}$ ao $9^{\circ}$ ano do Colégio Estadual Luís Navarro de Brito, em Alagoinhas-BA, a fim de despertar o interesse destes pelo estudo da Ciência, estimulando-os a consolidarem, junto com os educadores, a relação ensino-aprendizagem. As atividades foram organizadas em oficinas, desenvolvidas pelos bolsistas de Iniciação à docência, juntamente com os professores de Ciências. Os roteiros de aulas práticas foram definidos para cada experimento e executados pelos estudantes. Foram feitas indagações a estes e cada questionamento era respondido antes, durante e após os experimentos. Assim, notou-se um interesse e entusiasmo incomum nos educandos, em participar dos experimentos e responder às questões corretamente. Diante da análise, pode-se destacar e reiterar que o ensino de Ciências quando articula a prática com a teoria, torna as aulas mais interativas e a adesão dos educandos a ela se torna maior, sendo a participação dos pibidianos tanto importante para o sucesso das atividades, como para sua formação profissional, pois estes têm aprendido exitosamente a liderar atividades pedagógicas nas escolas (Coordenação de Aperfeiçoamento de pessoal do Nível Supeior-CAPES).

Palavras-chave: Experimentação; Ensino; Aprendizagem.

\section{INTRODUÇÃO}

É perceptível, nas escolas da rede básica de ensino, as dificuldades enfrentadas por professores de Ciências em construir o conhecimento com seus alunos, de forma contextualizada e prazerosa. Ensinar Ciências requer algo além da transmissão mecanizada de conteúdos, porque é necessário que nesse processo ocorra o despertamento da curiosidade dos educandos em relação ao que se vai estudar, permitindo que percebam a relevância do tema para 
sua vida. Desse modo, faz-se necessário estimular o aluno a relacionar a teoria desenvolvida em sala com a realidade a sua volta, sobretudo porque há dificuldade deste em reconhecer o conhecimento científico em situações do seu cotidiano. "Isso porque, com a experimentação, num processo investigativo, o aluno problematiza, questiona e põe à prova suas ideias, discutem suas práticas com outros alunos, o que resulta em um intenso ganho cognitivo" (WILSEK e TOSIN, 2012, p. 14).

O ensino de Ciências nas turmas de Ensino Fundamental II tem sido ainda alvo de muita discussão. Apesar de tantos cursos de formação continuada para profissionais dessa área, a falta de recursos necessários para que sejam executadas aulas práticas e de campo ainda são um problema a ser resolvido. Assim, as práticas ficam restritas a aulas expositivas, voltadas exclusivamente para a leitura dos livros didáticos e isso acaba contribuindo para a falta de interesse dos estudantes. Em contrapartida, os projetos de ensino e extensão de algumas Universidades têm contribuído para mudanças nessa realidade, tal como o Programa Institucional de Iniciação a Docência/PIBID-UNEB-CAPES, que ocorre em parceria com Escolas públicas. Isso tem permitido o desenvolvimento de atividades contextualizadas, aplicadas ao método científico e tem possibilitado aos docentes e discentes, a oportunidade de vivenciar na prática o estudo da Ciência, a partir de teste de hipóteses. Isso tem acontecido com os bolsistas do programa que atuam na Escola Estadual Luís Navarro de Brito, onde são propostas aulas práticas abordando diversos tipos de conteúdos.

Ensinar Ciências em turmas do ensino fundamental do $6^{\circ}$ ao $9^{\circ}$ ano requer, dos profissionais de ensino uma maior dedicação, pois a questão não está no que vai ser ensinado e sim como realizar tal processo.

O aluno precisa entender a relevância que tais conteúdos para seu cotidiano e cabe aos docentes explorar essas questões. Para Furman (2009, p.5), existe um consenso em relação à produção didática da ciência e a necessidade de os alunos aprenderem a resolver problemas, analisar informações, tomar decisões. O que significa desenvolver competências que possam prepará-los para a vida.

Conforme Arruda et al. (2006, p. 117):

\begin{abstract}
Nós, professores, podemos aproveitar a curiosidade natural dos alunos para despertar o interesse por ciência, incentivando o questionamento sobre o que ouvem ou leem na mídia. Mas há ainda que se considerar a importância das Ciências em diversas outras questões, que nem sempre estão em evidencia no noticiário, mas que são fundamentais para a formação do individuo. Por exemplo, o conhecimento do próprio corpo e a compreensão das mudanças que nele ocorrem na adolescência, os cuidados necessários para a prevenção de doenças, os riscos da automedicação e os cuidados que devemos ter com a segurança ao lidar com a rede elétrica ou com fogões a gás.
\end{abstract}

Dessa forma, o processo de ensino e de aprendizagem de Ciências em turmas do Ensino Fundamental II pode tornar-se prazeroso para ambas as partes. Tanto para os discentes quanto para os docentes, desde que esses fatores citados anteriormente sejam levados em consideração.

Segundo Arruda et al. (2006), o estudo de Ciências no ensino fundamental deve permitir ao educando a compreensão de conceitos científicos básicos e estabelecer relações entre estes e o mundo em que ele vive, considerando ainda a diversidade do contexto físico e cultural destes.

Mediante essas questões, vale ressaltar que estimular os alunos ao pensamento cientifico é de fundamental importância nos processos de ensino e aprendizagem de ciências, possibilitando que todos tenham as mesmas possibilidades de acesso aos saberes científicos. $\mathrm{O}$ objetivo do estudo foi relatar a experiência dos bolsistas de iniciação à docência da Universidade do Estado da Bahia, Departamento de Ciências Exatas, Campus II, na liderança de atividades experimentais em classes do ensino fundamental da Escola Estadual Luiz Navarro de Brito, do Município de Alagoinhas-BA. Assim, desenvolveu-se um trabalho experimental com estudantes do $6^{\circ}$ ao $9^{\circ}$ ano do colégio, buscando, além de despertar o interesse dos discentes pelo 
o estudo de Ciências, auxiliar os professores de Ciências na elaboração e execução de aulas práticas que contribuíssem para a melhoria da relação ensino-aprendizagem e proporcionassem um estreitamento das relações interpessoais entre docentes e discentes. Isso ocorreu em um sábado letivo, onde foram abordados diversos tipos de conteúdos relacionados ao método científico.

\section{METODOLOGIA}

O trabalho foi executado com os discentes do $6^{\circ}$ ao $9^{\circ}$ ano da educação básica do Colégio Estadual Luiz Navarro de Brito, Alagoinhas-BA. As atividades foram organizadas em oficinas, desenvolvidas pelos pibidianos da Universidade do Estado da Bahia-UNEB, Campus II (DCET - Interdisciplinar/CAPES) com os professores de Ciências da instituição parceira. Inicialmente foi apresentada uma palestra que tinha como tema "o método cientifico" e uma breve abordagem a respeito da Feira de Ciências da Bahia.

1. Os roteiros de aulas práticas foram definidos para cada experimento e executados pelos estudantes em um sábado letivo.

2. Foi apresentada uma palestra que tinha como tema o método cientifico e foi feita uma breve abordagem a respeito da Feira de Ciências da Bahia. Em seguida foi cedida a oportunidade aos bolsistas ID para a realização de experimentos descritos a seguir:

Extração do DNA do morango: Teve como objetivo demonstrar de forma prática a extração e identificação das moléculas de DNA do morango (PEREIRA, 2015).

A vela que levanta a água: este experimento teve como objetivo demonstrar um fenômeno relacionado à diferença de pressão (PEREIRA, 2015).

Misturas homogêneas e heterogêneas: O objetivo foi identificar os diferentes tipos de misturas (FONTAN, sd).

Foram feitas indagações aos discentes participantes dos experimentos e cada questionamento era respondido antes, durante e após os experimentos.

\section{RESULTADOS E DISCUSSÃO}

Durante o desenvolvimento das atividades foi possível notar um interesse e entusiasmo incomum dos educandos em participar dos experimentos e responder às questões corretamente. Isso reflete a necessidade de atividades experimentais para abordagem de determinados conteúdos, sobretudo "O método científico", pois aguça nos discentes, bem como os profissionais da educação a vontade de comprovar as hipóteses preestabelecidas, devido às vantagens que apresenta. Cassaro (2012) afirma que:

Tomar a experimentação como parte de um processo pleno de investigação é vista por parte de alguns docentes como uma necessidade, pois, a formação do pensamento e das atitudes do sujeito ocorre por intermédio de atividades investigativas Cassaro (, 2012, p.15).

Utilizar experimentos, no processo de ensino Ciências, em relação ao conteúdo trabalhado, foi bastante relevante, pois os alunos tiveram a oportunidade de aprender e senti-lo significativo para eles, sobretudo porque o foi apresentado de uma forma diferenciada, através da visualização dos processos na prática. Silva (2011) afirma que a superação de algumas dificuldades relacionadas à aprendizagem, assim como para torná-la atrativa para o aluno, é preciso envolver os estudantes em atividades que gerem motivação e significância para aprendêlo (Silva, 2011). Assim, cabe ao professor, como mediador da construção do conhecimento, propiciar um espaço na sala de aula que chame a atenção dos alunos utilizando-se de práticas 
pedagógicas motivadoras. Foi o que foi proporcionado pelos pibidianos sob supervisão da professora regente e da Coordenadora de Área do projeto.

Para Borges (2002), os professores de ciências, tanto no ensino fundamental como no médio, normalmente acreditam que a melhoria do ensino passa pela introdução de aulas práticas no currículo. Mas apesar disso, é difícil para eles fugirem da rotina de aulas tradicionais, baseadas em leituras de livros didáticos e exposições dos conteúdos nos quadros. Assim, a ideia de trabalhar com aulas práticas no sábado letivo, pelos pibidianos, foi relevante, pois promoveu o envolvimento do corpo docente e de todos os discentes da escola das turmas-alvo, desde a elaboração dos roteiros das práticas, até a execução das atividades, o que gerou uma ampla interação entre docentes, discentes e bolsistas ID.

Segundo Hodson (1988), o método científico é mais poderoso e efetivo quando consegue manipular os eventos, mas muitos dos eventos observados nos experimentos não ocorrem no mundo natural. Assim, para o mesmo autor, enquanto os experimentos científicos são conduzidos principalmente com o objetivo de desenvolver teorias, os experimentos do ensino de ciências têm uma série de funções pedagógicas. Isso foi notável nos experimentos desenvolvidos e relatados aqui, quando os principais objetivos definidos ao planejá-los, que foram despertar o interesse, motivar, promover o amadurecimento cognitivo e estabelecer socialização entre os envolvidos foram alcançados.

É notório que as atividades práticas podem permitir ao estudante imagens vividas e memoráveis de fenômenos interessantes para a compreensão dos conceitos científicos (BORGES, 2002). Partindo desse pressuposto, foi possível perceber o despertamento do interesse e a compreensão dos conceitos estudados por parte dos alunos, tanto na execução das atividades quanto nas respostas aos questionamentos levantados. Desse modo, CARDOSO (2013) destaca que as atividades práticas vêm ao encontro da crescente necessidade de se criar condições favoráveis ao aprendizado e ao desenvolvimento do potencial do estudante e do grupo. Assim, o bolsista ID juntamente com os professores trabalhou permitindo a construção de um ambiente favorável ao desenvolvimento dos processos de ensino e de aprendizagem, por meio das atividades práticas.

Vale ressaltar que os materiais utilizados para a realização dos experimentos fazem parte do quotidiano dos educandos. Assim, com poucos recursos, mas com senso criativo e vontade de realizar, dá para executar essas atividades satisfatoriamente. Diante das observações dos pibidianos e da sua atuação nas atividades propostas, pode-se destacar e reiterar que o ensino de Ciências quando articula a prática com a teoria, torna as aulas mais interativas e a adesão dos educandos a ela se torna maior.

\section{CONCLUSÕES}

Reitera-se que a utilização de aulas experimentais é importante para a construção do conhecimento científico, e por isso é extremamente importante para o ensino de Ciências.

É evidente a necessidade de uma formação crítica e qualificada dos licenciandos em Ciências Biológicas, que faça com que reflita sobre o papel da experimentação.

A aproximação entre a Universidade e a Escola é algo relevante, para auxiliar os professores que já estão atuando, através do desenvolvimento de projetos como o PIBID e também os desafiar a repensar suas práticas e suas concepções enquanto profissionais.

O PIBID tem permitido aos bolsistas ID protagonizar importantes papéis, junto ao professor regente, para promoção da mediação, para que a aprendizagem de fato aconteça. Para isso, as escolas tem sido um ambiente acolhedor que torna viável o sucesso das ações do projeto. 


\section{AGRADECIMENTOS}

Agradecemos ao PIBID/UNEB-CAPES pela concessão das bolsas de iniciação à docência e Coordenação de Área, bem como aos professores e alunos que colaboram conosco na execução de tais propostas, nos proporcionando experiências relevantes para nossa formação.

\section{REFERÊNCIAS}

ARRUDA, A. M. S.; BRANQUINHO, F. T. B.; BUENO, S. N. Ciências no Ensino Fundamental. 2006.

BORGES, A. T. Novos rumos para o laboratório escolar de Ciências. Caderno Brasileiro de Ensino de Física, v. 19, n. 3, 2002.

CARDOSO, F. S. O uso de atividades práticas no ensino de Ciências: na busca de melhores resultados no processo ensino aprendizagem. Lajeado: Centro Universitário UNIVATES, 2013.

CASSARO, R. Atividades experimentais no ensino de Física. Ji-Paraná: Universidade Federal de Rondônia, 2012.

FONTAN, A. P. Química Geral I Experimental $1^{\circ}$ Período. CEFET Química Unidade Rio de Janeiro, sd.

FURMAN, M. O ensino de Ciências no Ensino Fundamental: colocando as pedras fundacionais do pensamento científico. Sangari Brasil. 2009.

HODSON, D. Experimentos na ciência e no ensino de ciências.Educational philosophy and theory, v. 20, n. 2, p. 53-66, 1988.

PEREIRA, S. G et al. Manual de aulas práticas de Ciências e Biologia - Compêndio /Alunos do $4^{\circ}$ Período de Ciências Biológicas.Faculdade da Cidade de João Pinheiro: [s.n.], 2015.

SILVA, R. F. et al. O ensino de Biologia e as atividades experimentais: uma aposta motivacional para aprendizagem. 2011.

WILSEK, M. A. G.; TOSIN, J. A. P. Ensinar e aprender ciências no Ensino Fundamental com atividades investigativas através da resolução de problemas. Estado do Paraná, v. 3, n. 5, p. 1686-1688, 2012. 